\title{
NEW SPECIES AND NOMENCLATURAL NOTES IN ACIANTHERA FROM BRAZIL
}

\author{
A. L. V. Toscano de Brito ${ }^{1,3} \&$ Carlyle A. Luer ${ }^{2}$ \\ ${ }^{1}$ Marie Selby Botanical Gardens, 811 South Palm Avenue, Sarasota, FL 34236-7726 U.S.A. \\ ${ }^{2}$ Missouri Botanical Garden, 2345 Tower Grove Avenue, St. Louis, Missouri 63110, U.S.A. \\ Corresponding address: 3222 Old Oak Drive, Sarasota, FL 34239-5019 U.S.A. \\ ${ }^{3}$ Corresponding author: atoscano@selby.org
}

\begin{abstract}
Aвstract. Two new Brazilian species of the orchid genus Acianthera, Acianthera calopedilon and Acianthera cephalopodiglossa, are described and illustrated. The identities of Acianthera bidentula, Acianthera saundersiana, and Acianthera serpentula are discussed. Acianthera velteniana, recently described for Espírito Santo, is placed in the synonymy of Acianthera bidentula. An epitype is selected for Pleurothallis saundersiana and a lectotype for Pleurothallis serpentula. Updated synonymy lists are provided for the taxa treated in the article.
\end{abstract}

Key words: Acianthera bidentula, Acianthera calopedilon, Acianthera cephalopodiglossa, Acianthera saundersiana, Acianthera serpentula, Acianthera velteniana, Pleurothallidinae

Introduction. The genus Acianthera Scheidw. comprises over two hundred Neotropical species. The World Checklist of Selected Plant Families (WCSP, accessed 17 Sept. 2014) published online by the Royal Botanical Gardens, Kew, lists 286 valid names of which 121 names have been recently reported from Brazil (Chiron \& van den Berg 2012; Barros et al. 2014). As neither of these accounts on Brazilian species presents a taxonomic revision of the genus and because there still are several obscure and problematic taxa, including a number of yet undescribed species (Toscano de Brito \& Luer, in prep.), this latter number is obviously provisional and will certainly change in the future.

While preparing a taxonomic revision of the Brazilian Acianthera, the authors discovered two new species that belong to a complex of long-repent, similar taxa, henceforth referred to as Acianthera saundersiana complex. Chiron \& van den Berg (2012) assigned some species of this complex to Acianthera sect. Sicariae subsect. Auritae Chiron \& van den Berg. Species in this group are uncommon in Peru and Bolivia but frequent and variable in southern Brazil where it has accumulated a long list of epithets from several authors. Of about 30 binomials published in this complex, the most familiar is undoubtedly Acianthera saundersiana (Rchb.f.) Pridgeon \& M.W.Chase.
After studying all protologues and available type specimens in this species complex, it has become clear that several names have been consistently misidentified and confused in herbaria and literature. A number of published illustrations have been wrongly named (e.g. Cogniaux 1896; Pabst \& Dungs 1975; Chiron \& Bolsanello 2010), and several specimen citations in floristic treatments are in fact a mixture of different taxa (e.g. Cogniaux 1896). Therefore, the taxonomy of this species group is highly confused. It is, however, beyond the scope of this work to discuss or review in detail all published names in this complex. This will be part of a forthcoming taxonomic revision of the genus, which is currently in preparation by the authors.

In this article we describe two new species, Acianthera calopedilon Toscano \& Luer and $A$. cephalopodiglossa Toscano \& Luer. We briefly discuss the identity of Pleurothallis bidentula Barb. Rodr. [ $=$ A. bidentula (Barb.Rodr.) Pridgeon \& M.W.Chase], Pleurothallis saundersiana Rchb.f. $(=$ A. saundersiana $)$ and Pleurothallis serpentula Barb.Rodr. [= A. serpentula (Barb.Rodr.) F.Barros], and the name A. velteniana Chiron \& Xim.Bols. is placed in the synonym of $A$. bidentula. An epitype is selected for $P$. saundersiana and a lectotype for $P$. serpentula. 

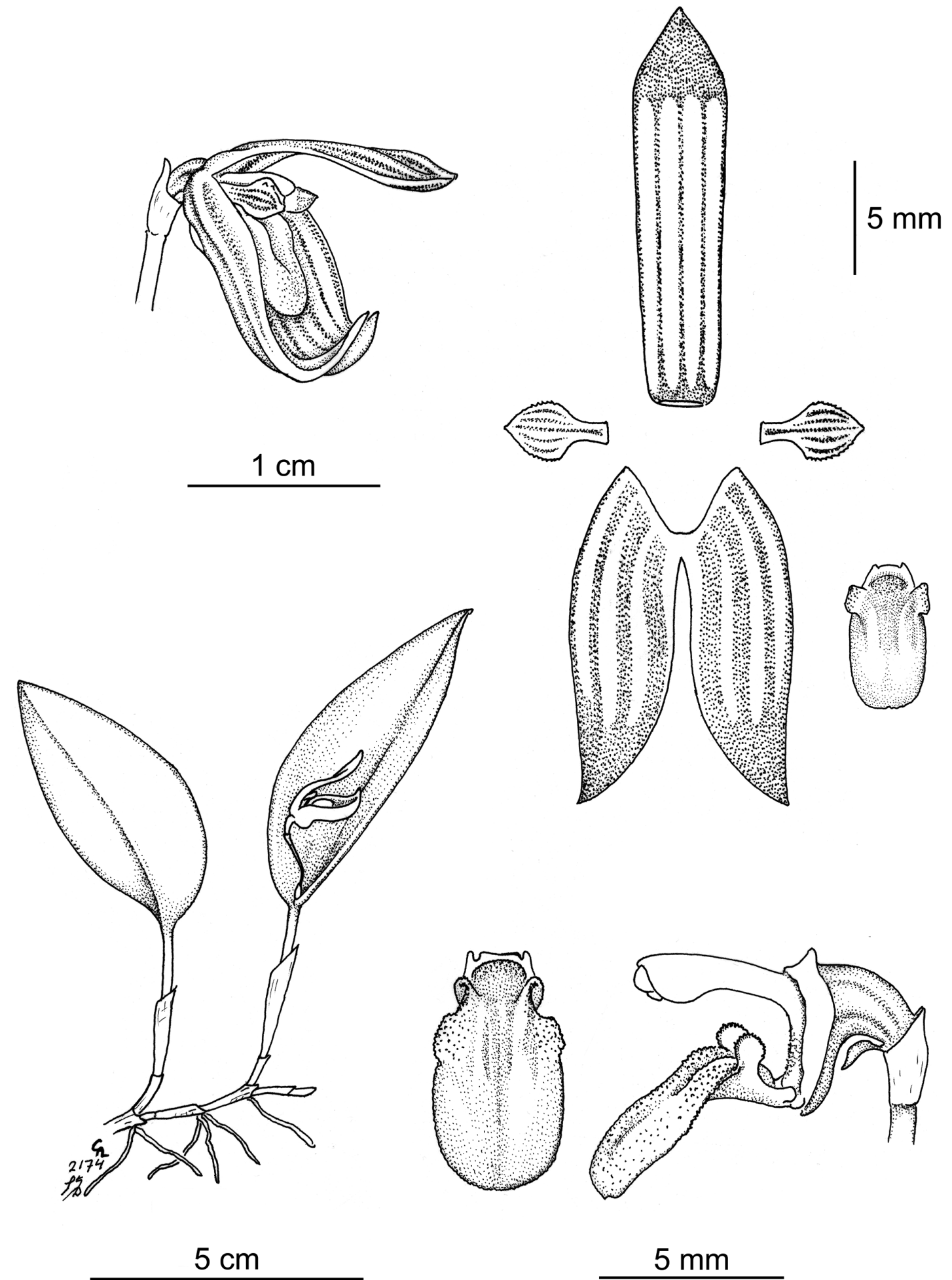

Figure 1. Acianthera calopedilon Toscano \& Luer. Drawn by C.A. Luer based on C.A. Luer 2174 (SEL). 


\section{New Species}

Acianthera calopedilon Toscano \& Luer, sp.nov.

TYPE: Brazil. Paraná: road Alexandra to Matinhos, collected and cultivated by M. Klingelfus s.n., flowered in cultivation, 7 Oct. 2011, A. Toscano de Brito 2911 (Holotype: UPCB). Fig. 1-2.

Plant medium in size, epiphytic, long-repent, the rhizome $0.5-2.5 \mathrm{~cm}$ long between ramicauls; roots slender. Ramicauls ascending, suberect, 2-5 cm long, enclosed by 2 loose, tubular sheaths toward the base. Leaf suberect, coriaceous, elliptical, acute, $4.5-7.5 \mathrm{~cm}$ long, 2.3-3.0 cm wide, the base shortly cuneate, sessile. Inflorescence a single flower or a fascile of 2 successively flowers, from the apex of the ramicaul at the base of the leaf, with a spathe $3 \mathrm{~mm}$ long; peduncles $6.0-8.5 \mathrm{~mm}$ long; floral bract tubular, 2.2-3.0 mm long; pedicels 2.0 $2.5 \mathrm{~mm}$ long; ovary 2--3 mm long; sepals ivory to slightly greenish, densely striped with deep purple, the apical portion and the margins purple, the dorsal sepal oblongobovate or oblong-lanceolate, acute, $13.5-17.0 \mathrm{~mm}$ long, 4.5-5.0 mm wide, 3-veined, free from the lateral sepals, the lateral sepals connate (easily separating) into an

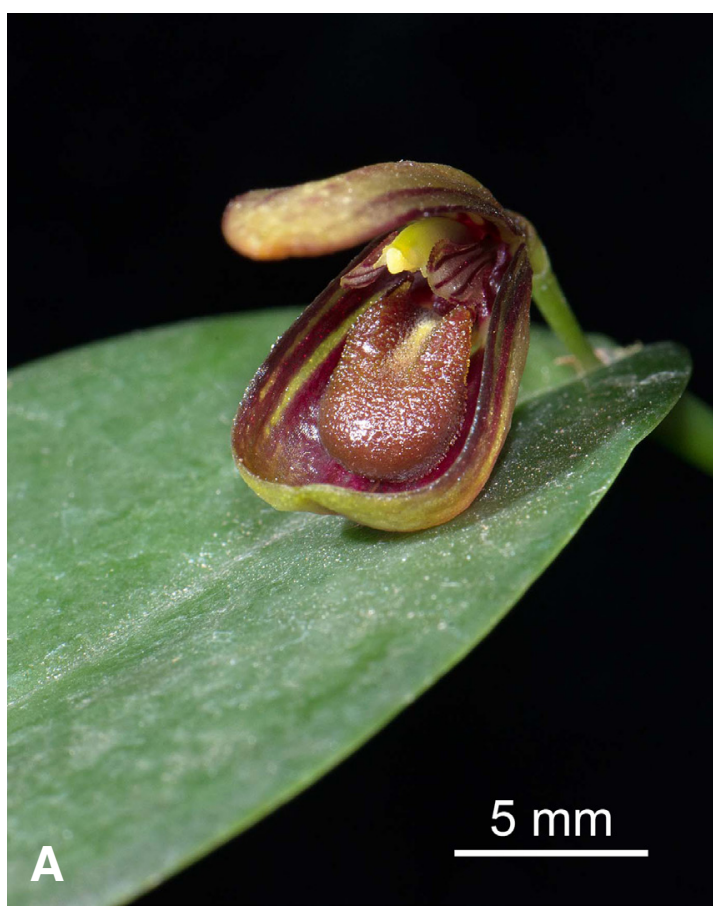

elliptical, concave, usually incurved, acute, shortly bifid lamina, 13-15 mm long, 4.5-7.0 mm wide unexpanded, 6-veined; petals translucent-ivory, with three purple veins, occasionally with two outer, obscurely verrucose purple stripes, spathulate, unguiculate, serrate-fimbriate above the lower third, acute or subacute, 4.5-5.5 mm long, 2.0-2.5 mm wide; lip deep purple, thick, rigid, fleshy, verrucose, trilobed, convex toward the apex, 6.0-6.5 mm long, 3.5-4.0 mm wide, with the margins deflexed and minutely denticulate, the apex broadly rounded, the marginal lobes, on the lower quarter, small, erect, subobovate-auriculate, the disc shallowly sulcate between a low pair of verrucose calli on the middle third, anterior to the marginal lobes, the base truncate, minutely lobed at the angles, hinged to the column-foot; column greenish-white, semiterete, slightly winged above the middle, minutely denticulate at the apex, 4-5 mm long, the foot thick, $3 \mathrm{~mm}$ long, the anther, rostellum and stigma ventral.

Distribution: This species occurs from Espírito Santo (L.F. Varella, pers. com. 2014), in southeast Brazil, to Paraná and Rio Grande do Sul, in the south. It reaches Argentina in its southernmost distribution.

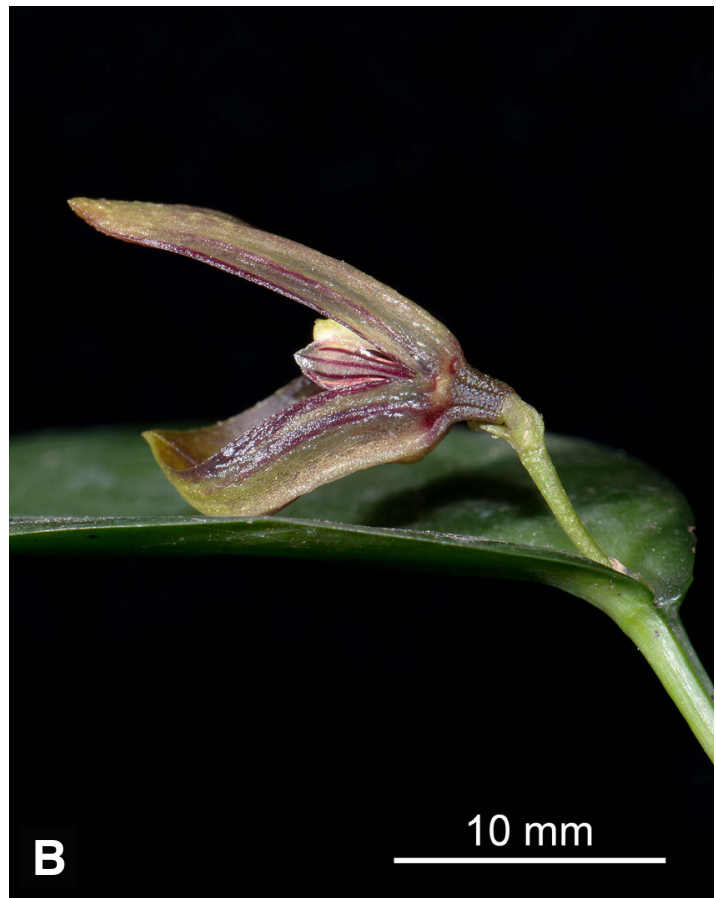

Figure 2. Acianthera calopedilon Toscano \& Luer. A - Flower in front view. B - Flower in side view. Photographs by Wade Collier based on A. Toscano de Brito 3272 (UPCB). 
Eтymology: The specific epithet derives from the Greek kalopedilon, "a wooden shoe," and refers to the shape of the synsepal, which resembles the Dutch allwooden shoes or clogs.

Acianthera calopedilon is common in private collections and usually confused with $A$. saundersiana, from which it is distinguished by the distinct convex, broadly obtuse lip. It is similar to $A$. cephalopodiglossa, also described herein, with which it has been also confused, but differs mainly in the shape of lateral sepals and lip (see discussion under $A$. cephalopodiglossa). Photographs of specimens of $A$. calopedilon have been labelled "Acianthera andreana" in a few websites (e.g. http://www.aorquidea.com.br/ forum/viewtopic.php?t=22299\&sid=3f84b872ebc1fd 5 ea4c215db21ac51e7) but this name has never been validly and effectively published.

Additional Material Examined: BRAZIL: São Paulo, collected by Bauman s.n. from trees along the roadside between São Paulo and Santos, 170 m, May 1976, flowered in cultivation in Easton, Connecticut, 12 Nov. 1977, C.A. Luer 2174 (SEL). Paraná: without precise locality, collected and cultivated by M. Klingelfus s.n., flowered in cultivation 7 Oct. 2011, A. Toscano de Brito 2910 (UPCB). Rio Grande do Sul: Santa Vitória do Palmar, Taim, 20 m, collected by Sérgio Englert, flowered in cultivation L.F. Varella s.n., 19 July 2014, A. Toscano de Brito 3272 (UPCB). ARGENTINA: without precise locality, obtained from Rita Franke in Argentina, flowered in cultivation, 14 Nov. 2003, B. Rinke s.n. (SEL-OIC 15729).

Acianthera cephalopodiglossa Toscano \& Luer, sp. nov.

TYPE: Brazil. São Paulo: Registro, near sea level, flowered in cultivation, 24 March 2007, J.L.M. André s.n. (Holotype: MBM), C.A. Luer illustr. 21182. Fig. 3.

Plant medium in size, epiphytic, long-repent, the rhizome $1.5-3.0 \mathrm{~cm}$ between ramicauls; roots slender. Ramicauls ascending, erect, slightly compressed and sulcate, 4-7 cm long, with 2 tubular sheaths, one below the middle and another sheath at the base. Leaf suberect, coriaceous, broadly elliptical, 5.5-6.5 cm long, 2.0-2.5 $\mathrm{cm}$ wide, obscurely notched, acute to subobtuse, the base sessile, obtuse to broadly cuneate. Inflorescence a fascicle of successive, single flowers, from the apex of the ramicaul at the base of the leaf, with a spathe 5 $\mathrm{mm}$ long; peduncles $10-12 \mathrm{~mm}$ long; floral bracts 2 $\mathrm{mm}$ long; pedicel $3 \mathrm{~mm}$ long; ovary $2 \mathrm{~mm}$ long; sepals gray with dark purple veins, glabrous, the dorsal sepal oblong-lanceolate, acute, concave below the middle, convex and slightly recurved on the apical third, free from the laterals, $17 \mathrm{~mm}$ long, $5 \mathrm{~mm}$ wide, 3-veined, slightly carinate on the midvein; lateral sepals connate to the apex into a concave, acute, broadly ellipticalobovate synsepal, $16 \mathrm{~mm}$ long, $8 \mathrm{~mm}$ wide expanded, 6-veined, obscurely bicarinate; petals same color as sepals, lanceolate-spathulate, acute, margins minutely denticulate on the apical half, $5.5 \mathrm{~mm}$ long, $1 \mathrm{~mm}$ wide, 3-veined; lip dark purple, obovate-oblong, trilobed, rigid, coarsely verrucose on the upper surface, $8 \mathrm{~mm}$ long, $4 \mathrm{~mm}$ wide, 3 -veined, the lateral lobes below the middle, erect, rounded, the disc shallowly channeled between a pair of parallel, crested calli on the middle third, the margins erose-denticulate, incurved at the convex apical third, the lateral margins of the apical third folded and auriculate, the base callose, truncate, minutely biauriculate, hinged to the column-foot; column semiterete, winged above the middle, minutely denticulate at the apex, $5 \mathrm{~mm}$ long, the foot $2.5 \mathrm{~mm}$ long, the anther, rostellum and stigma ventral.

Distribution: So far, this species is only known for the municipality of Registro, State of São Paulo, southeastern Brazil.

Eтymology: From the Greek kephalópoda (= Cephalopoda), a class of mollusks in which octopuses are included, and the Greek element glossa (= tongue), in reference to the lip, which resembles the head and mantle of an octopus.

In habit and size of flowers, Acianthera cephalopodiglossa is similar to large forms in the $A$. saundersiana complex and to A. calopedilon. It is readily distinguished from these and all other Acianthera species by the peculiar shape of its verrucose, rigid lip: the apical half is convex and folded on the lateral margins, each fold forming two auricles, the whole lip resembling the head and mantle of an octopus.

\section{Nomenclatural note on Acianthera saundersiana}

Acianthera saundersiana (Rchb.f.) Pridgeon \& M.W.Chase, Lindleyana 16: 246. 2001. Fig. 4-6. 

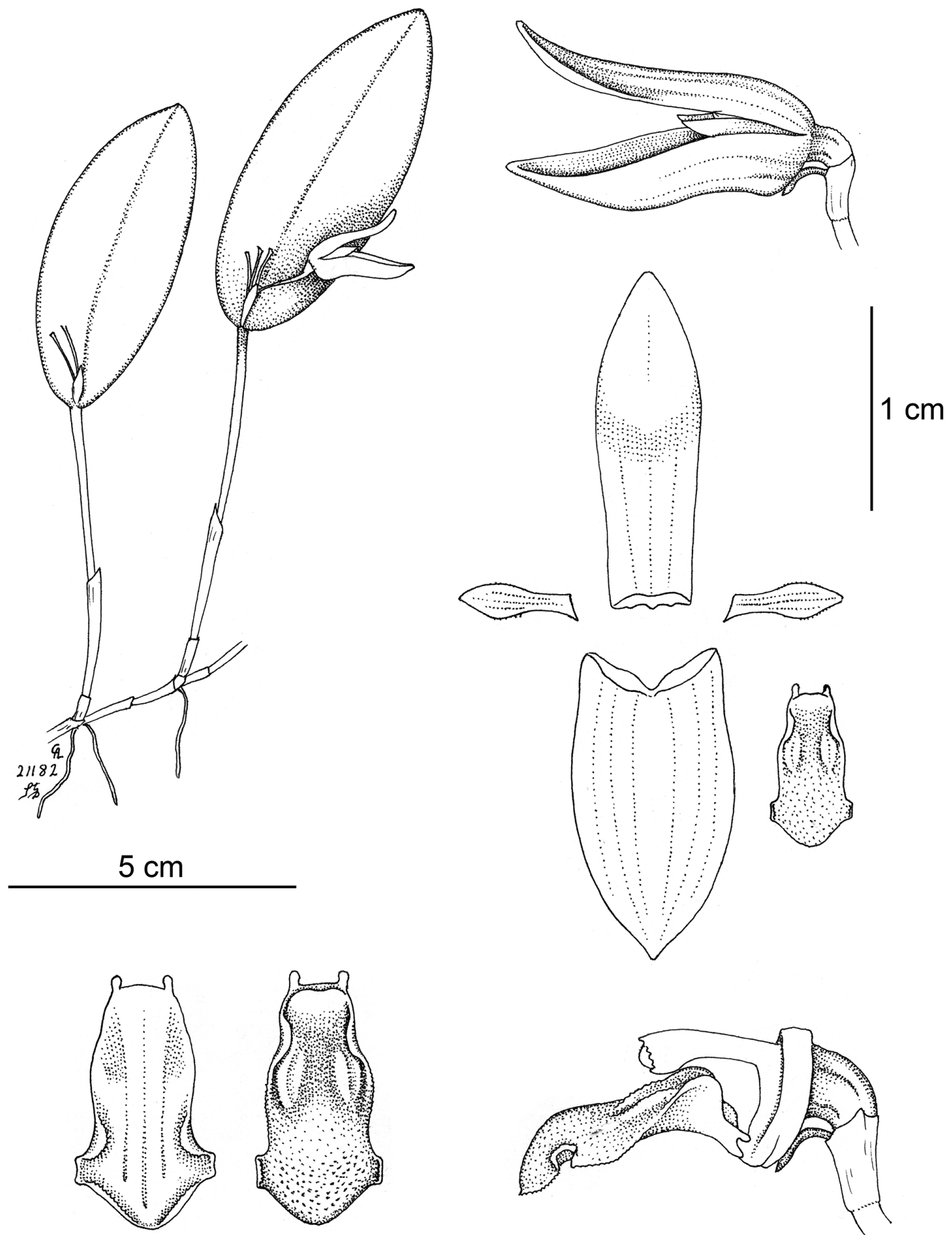

\section{$4 \mathrm{~mm}$}

Figure 3. Acianthera cephalopodiglossa Toscano \& Luer. Drawn by C.A. Luer based on the holotype, J.L.M. André s.n. (MBM). 
Basionym: Pleurothallis saundersiana Rchb.f., Gard. Chron. 74. 1866. TYPE: [BRAZIL?]: without collection data, imported by Messieurs Linden of Brussels, cultivated at Reigate, England, by W.W. Saunders s.n. (Holotype: W; Epitype selected here: original plate prepared by W.H. Fitch now kept in the illustration collection in the orchid herbarium at K, reproduced in Saunders's Refug. Bot. 2, tab. 120. 1872).

Synonyms: Pleurothallis felislingua Barb.Rodr., Gen. Sp. Orchid. 2: 18. 1881. TYPE: BRAZIL. Rio de Janeiro, Rodeio, J. Barbosa Rodrigues s.n. (Holotype: Lost; Lectotype selected by Chiron \& Bolsanello in Richardiana 10(4): 203. 2010, here clarified: tab. 158, fig. A, vol. 3 in Iconogr. Orchid. Brésil at the Library of Rio de Janeiro Botanical Garden, cited as tab. 543 (then unpublished) in Barb.Rodr. loc.cit; copied and reproduced in black and white in Cogn., F1. Bras. (Martius) 3(4), tab. 97, fig. 1. 1896; reproduced in color in Sprunger et al., 1996, vol. 1: 216, fig. A, as "Pleurothallis saundersiana").

Pleurothallis josephensis Barb.Rodr., Vellosia, ed. 2, 1: 116. 1891. TYPE: BRAZIL. Minas Gerais, Serra de São José Del Rei, J. Barbosa Rodrigues s.n. (Holotype: Lost; Lectotype selected by Chiron \& Bolsanello in Richardiana 10(4): 203. 2010, here clarified: tab. 160, fig. E, vol. 3 in Iconogr. Orchid. Brésil at the Library of Rio de Janeiro Botanical Garden, cited as tab. 825 (then unpublished) in Barb.Rodr. loc.cit; copied and reproduced in black and white in Cogn., Fl. Bras. (Martius) 3(4), tab. 93, fig. 5; reproduced in color in Sprunger et al., 1996, vol. 1: 218, fig. E, as "Pleurothallis saundersiana").

Pleurothallis repens Rolfe, Bull. Misc. Inform. Kew 1912: 131. 1912, nom. illeg., non Ames 1908. TYPE: Brazil. Without precise locality, imported and found amongst a clump of Laelia purpurata, flowered in cultivation 6 Jan. 1904 (not mentioned in the protologue), F. Wigan s.n. (Holotype: K).

Pleurothallis juergensii Schltr., Repert. Spec. Nov. Regni Veg. Beih. 35: 54. 1925. TYPE: Brazil. Rio Grande do Sul, Rio Pardo, Fazenda Boa Esperança, 70 m, March 1921, C. Jürgens 20 (Holotype: B, destroyed).
Pleurothallis insularis Hoehne \& Schltr., Arch. Bot. São Paulo 1(3): 217. 1926. TYPE: Brazil. São Paulo, Ilha da Queimada, 6 April 1921, A. Gehrt s.n. (Holotype: B, destroyed; Lectotype: SP, designated by Barros in Orchid Memories: 17. 2004).

Pleurothallis josephensis var. integripetala Hoehne, Arch. Inst. Biol. (São Paulo) 2: 22. 1929. TYPE: Brazil. São Paulo, fl. cult. 20 May 1897, G. Edwall ex Comissão Geográfica e Geológica de São Paulo nr. 3705 (Holotype: SP).

Pleurothallis josephensis var. papillifera Hoehne, Arch. Inst. Biol. (São Paulo) 2: 22. 1929. TYPES: Brazil. São Paulo, Piassaguera, 14 March 1923, A. Gehrt s.n. (Syntype: SP 8236); São Paulo, Ilha da Queimada, 6 April 1921, A. Gehrt s.n. (Syntype: SP 5452, also the lectotype of $P$. insularis Hoehne \& Schltr.). São Paulo, Serra Negra, 1 June 1927, F.C. Hoehne s.n. (Syntype: SP 20633, not located).

Pleurothallis josephensis var. subcrenulata Hoehne, Arch. Inst. Biol. (São Paulo) 2: 22. 1929. TYPE: Brazil. Minas Gerais, Pouso Alegre, 1 May 1927, F. Hoehne s.n. (Holotype: SP).

Pleurothallis ascendens Garay, Arch. Jard. Bot. Rio de Janeiro 12: 171.1953, replacement name for Pleurothallis repens Rolfe.

Specklinia saundersiana (Rchb.f.) F.Barros, Hoehnea 10: 110.1983 [publ. 1984].

Acianthera insularis (Hoehne \& Schltr.) Luer, Monogr. Syst. Bot. Missouri Bot. Gard. 112: 118. 2007.

Reichenbach described this species in 1866 as Pleurothallis saundersiana, based on a specimen obtained by William Wilson Saunders of Hillfield House at Reigate, Surrey, England and whose epithet it honors. No published illustration of this species was known until 1872, when a detailed, partially colored plate was published in Saunders's Refugium Botanicum, tab. 120. Reichenbach stated in the protologue that this species was believed to have been imported from Brazil by Hugh Low, from Clapton Nursery, London. However, a note by Saunders in Refugium Botanicum (1872) says that he received it from Messieurs Linden of Brussels.

According to Reichenbach (1872), Saunders suggested that the plant might have come from Popayan, Colombia. Although the correct provenance of the specimen cannot be ascertained, it seems that it 


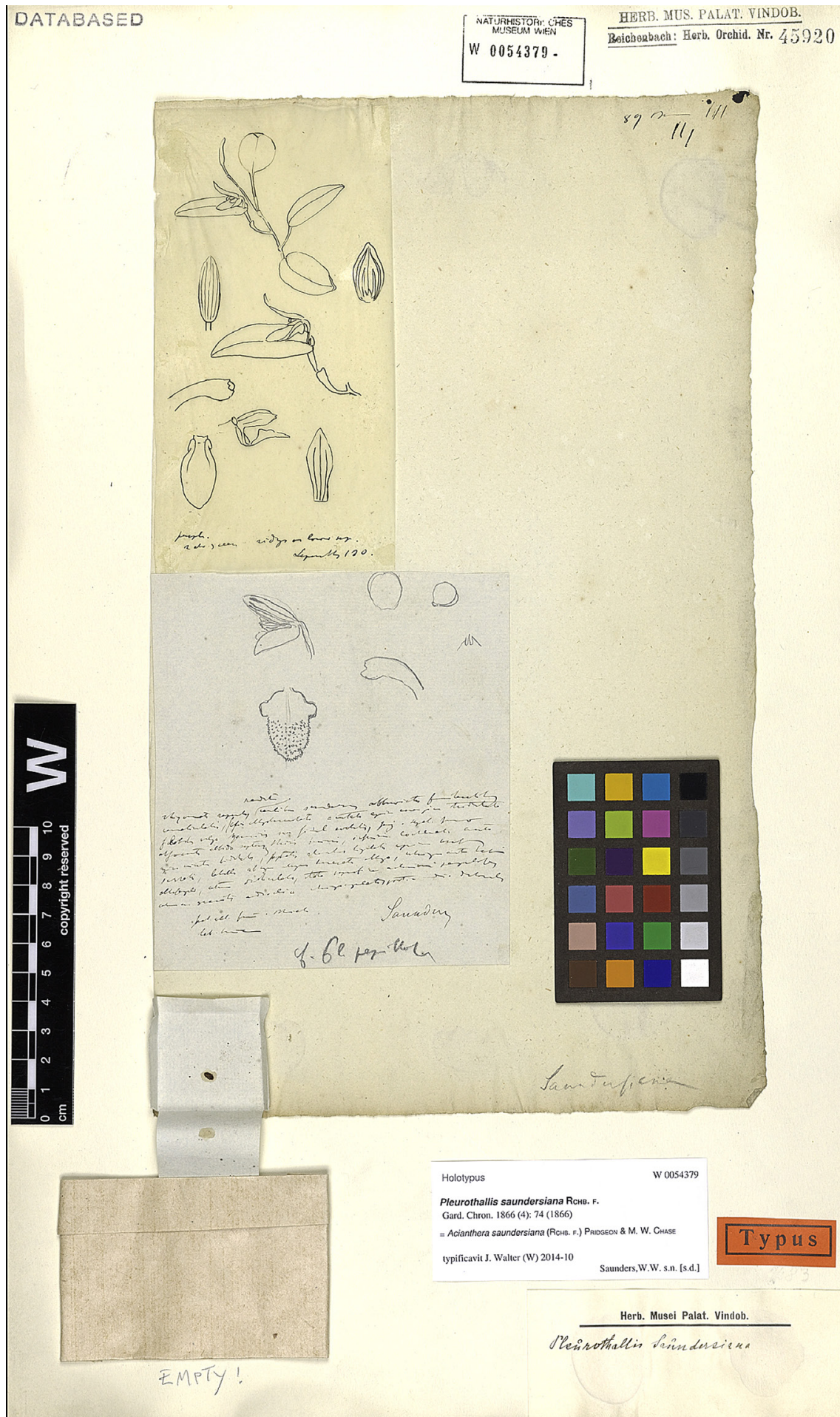

Figure 4. Holotype of Pleurothallis saundersiana Rchb.f. at W. By permission of the Keeper, Herbarium Natural History Museum in Vienna. 


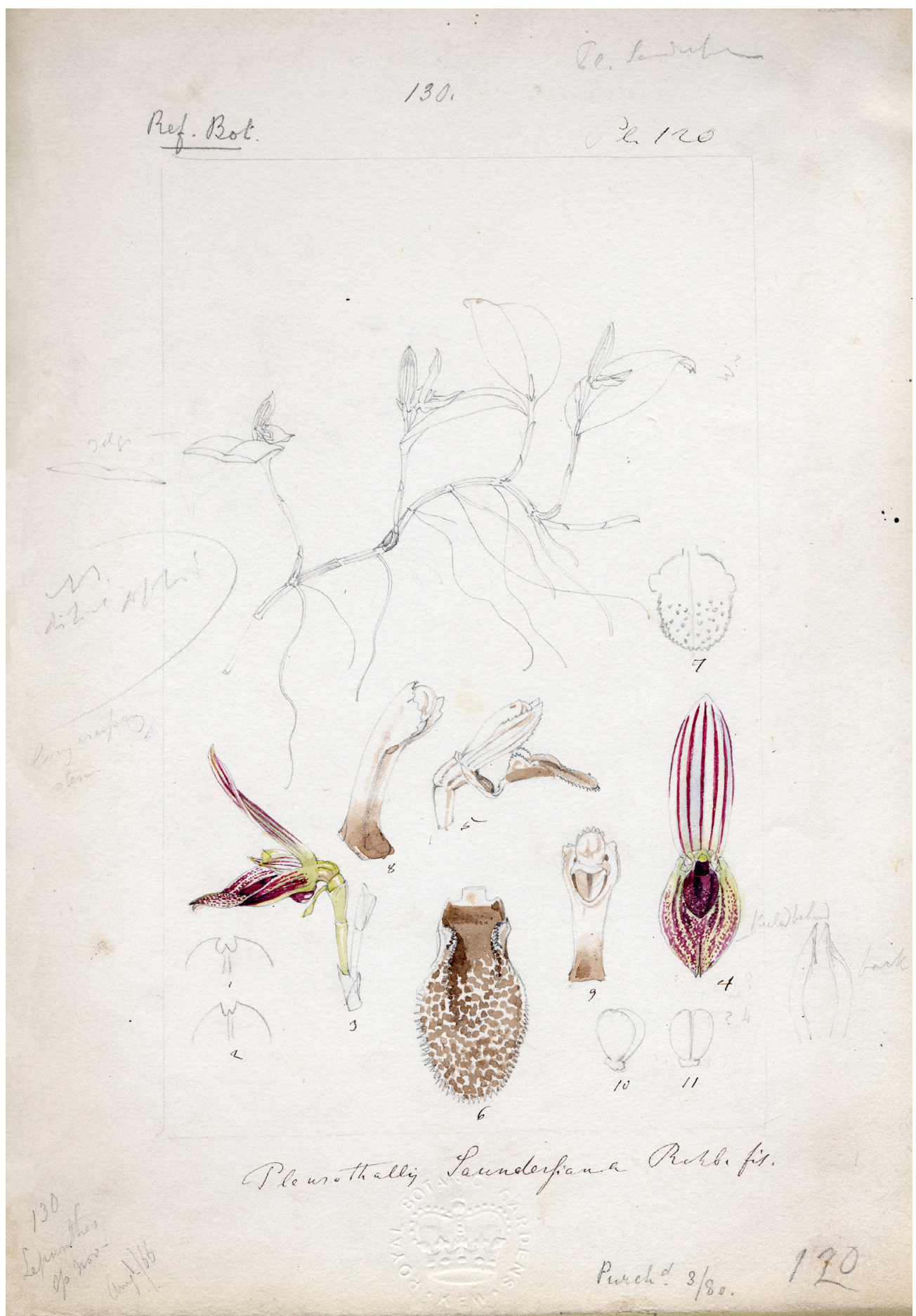

FIGURE 5. Epitype of Pleurothallis saundersiana Rchb.f., proposed here. Original plate prepared by Walter Fitch and reproduced in Refugium Botanicum plate 120. Reproduced with the permission of the Board of Trustees of the Royal Botanic Gardens, Kew. 
was in fact Brazilian in origin as stated by Luer (1977), as this species is common and widespread in Brazil. Still writing in Refugium Botanicum, Reichenbach (1872) listed the materials that he had seen of this species, namely: Saunders's specimen and sketches, and his own sketches and description. The type sheet at W (Fig. 4) contains the two cited sketches but the actual specimen seems to have been lost. With the exception of an almost disintegrated lip in one of two envelopes glued on the sheet, nothing else exists. This lip is about $4 \mathrm{~mm}$ long and $2 \mathrm{~mm}$ wide and agrees well with the drawings on the type sheet and those shown on plate nr. 120 of Refugium Botanicum. It is possible that this plate has been based on a clone of Saunders's collection sent to Reichenbach, or probably on a specimen from the same gathering, which might have flowered later in cultivation at Reigate. Reichenbach (1872) stated that he did not see the plant depicted on the Refugium plate 120 and that he could not understand the "three flowering stems at once and one of them also two-flowered at once." Nonetheless, this is a common feature, not only in this species but also in other taxa of this complex. As the type of Pleurothallis saundersiana contains drawings and only a fragmented lip, we have selected as epitype the original plate (Fig. 5) prepared by the Scottish botanical artist, Walter Hood Fitch (1817-1892), and reproduced in Refugium Botanicum plate 120. Fitch's drawings are now kept in the illustration collection in the orchid herbarium at $\mathrm{K}$.

The drawings and fragmented lip on the type sheet and the selected epitype agree well with the illustrations presented by Luer $(1977,2004)$ and with a collection from Rio de Janeiro that flowered in cultivation at Rio de Janeiro Botanical Garden in 1989 (Fig. 6). They also agree with the types of the taxa placed herein in synonymy and with collections from Peru and Bolivia that we have studied.

Acianthera saundersiana is a variable species and quite common in the Atlantic forests of southeastern Brazil. An assortment of names has been assigned to its synonymy (e.g. Barros et al. 2014; Luer 1977, 2004; Chiron \& Bolsanello 2010). However, some of these names represent valid species, others are synonyms of distinct species, while a few possess no extant types or usable flowers and could refer to other similar taxa in this complex. We have updated the synonymy of $A$. saundersiana based on the examination and study of types and protologues of various taxa. The synonymy list represents the current knowledge by the authors and might slightly change to include additional binomials in the future. With exception of A. bidentula, which is also discussed herein, the excluded binomials will be treated in forthcoming articles.

Plants of Acianthera saundersiana are epiphytes and possess a long-repent rhizome that gives rise to a series of suberect to erect ramicauls, $2-5 \mathrm{~cm}$ long, each with a sessile, broadly or narrowly elliptical leaf about equally long. From the base of the leaf, a relatively large, short pedunculate, bilabiate flower is produced singly or in a successively two-flowered raceme. The sepals are fleshy and mottled, suffused or striped with purple or brown, the dorsal is slightly longer than the lateral ones, $11-12 \mathrm{~mm}$ long, 3-4 mm wide, the laterals $8-10 \mathrm{~mm}$ long, $5.0-6.5 \mathrm{~mm}$ wide. The petals are small, narrowly obovate, acute, denticulate or erose, 2.5-4.0 $\mathrm{mm}$ long, $1.0-1.5 \mathrm{~mm}$ wide. The lip 3.5-5.0 mm long, 2-3 mm wide, usually very dark purple, sometimes almost black, thick and oblong with small, marginal, erect, denticulate lobes below the middle, a pair of verrucose calli on the middle third, and a minute lobule at each corner of the base. The column $2.5-3.5 \mathrm{~mm}$ long and foot 1.5-2.0 $\mathrm{mm}$ long.

As said above, the taxonomy of Acianthera saundersiana and other species in this complex has been problematic and confusing since the time of its publication in 1861. Chiron \& Bolsanello (2010) attempted to review this species complex in Espírito Santo, southeast Brazil. Unfortunately, most illustrations presented in Chiron \& Bolsanello (2010) are crude, lack detail and are therefore misleading. Several of them can fit any of the many species in this complex.

Additional Material Examined: BRAZIL: Without locality, flowered in cultivation in the Jardim Botânico do Rio de Janeiro, 28 Nov. 1989, C.A. Luer 14487 (SEL). PERU: Amazonas: near Chachapoyas, cultivated in Tacoma, WA, 1993, K. Tokach 17 (MO), C.A. Luer illustr. 17028. BOLIVIA: La Paz: North of Yungas, wet forest near Rio Coroico, $1100 \mathrm{~m}$, collected in Jan. 1980, flowered in cultivation at SEL 80-235, 30 March 1981, C.A. Luer et al. 5603 (SEL); Santa Cruz: collected by Janet Kuhn with Fred Fuchs, probably in 1973, cultivated at J \& L Orchids, Easton, CT., 29 Oct. 1975, C.A. Luer 592 (SEL). 

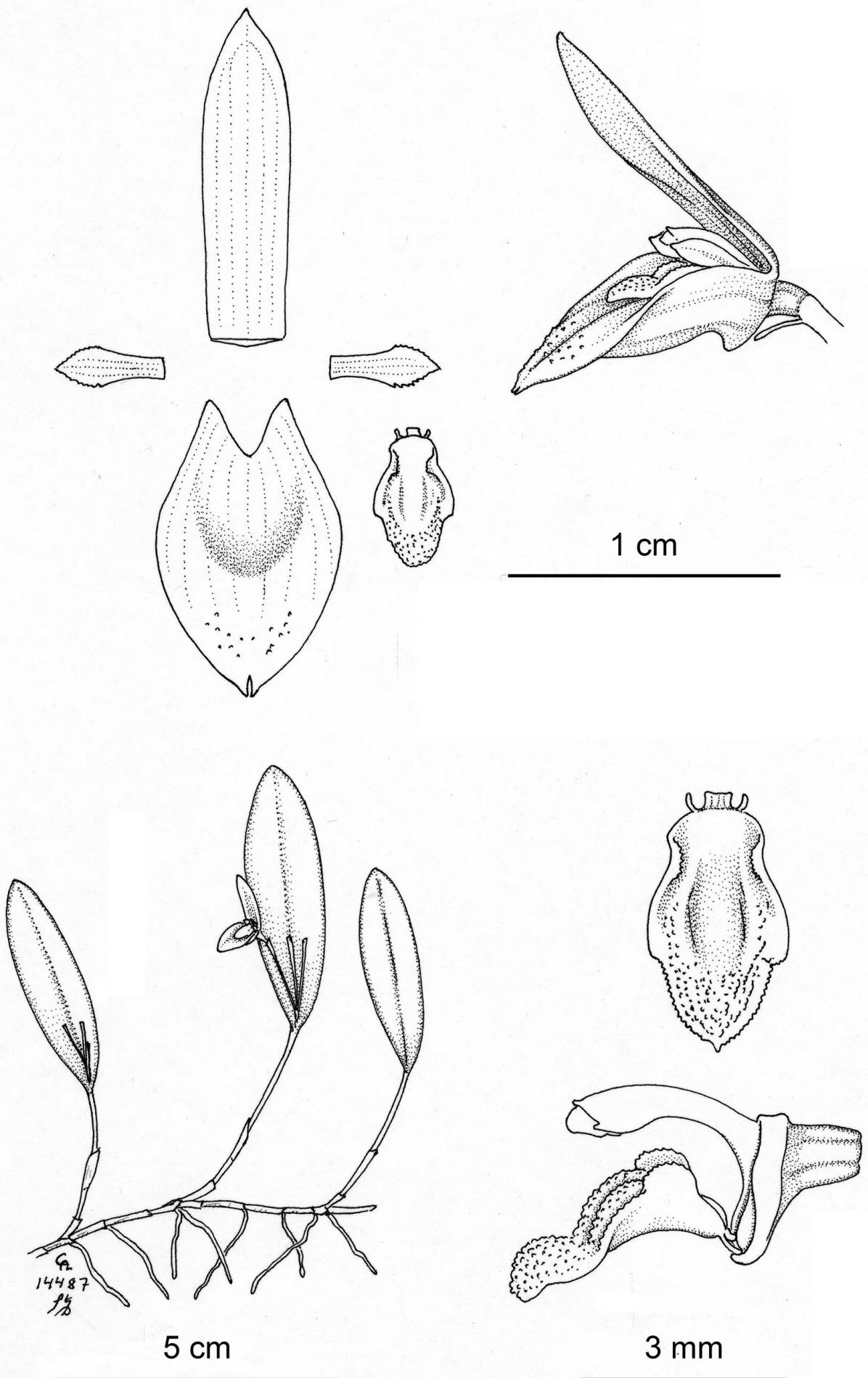

FiguRE 6. Acianthera saundersiana (Rchb.f.) Pridgeon \& M.W.Chase. Drawn by C.A. Luer based on C.A. Luer 14487 (SEL). 


\section{Nomenclatural note on Acianthera bidentula}

Acianthera bidentula (Barb.Rodr.) Pridgeon \& M.W.Chase, Lindleyana 16: 242. 2001. Fig. 7-8.

Basionym: Pleurothallis bidentula Barb.Rodr., Revista Engen. 3(7): 109. 1881. TYPE: BRAZIL. Rio de Janeiro, Palmeiras, J. Barbosa Rodrigues s.n. (Holotype: Lost; Lectotype selected by Chiron \& Bolsanello in Richardiana 10(4): 201. 2010, here clarified: tab. 158, fig. B, vol. 3, in Iconogr. Orchid. Brésil at the Library of Rio de Janeiro Botanical Garden, cited as tab. 728 (then unpublished) in Barbosa Rodrigues (1881, 1882); copied and reproduced in black and white in Cogn., Fl. Bras. (Martius) 3(4), tab. 93, fig. 4. 1896; reproduced in color in Sprunger et al. (1996, vol. 1: 216, fig. B).

Synonyms: Pleurothallis vinosa Hoehne \& Schltr., Arch. Bot. São Paulo 1: 227. 1926. TYPE: Brazil. São Paulo: Prata, 29 March 1920, F.C. Hoehne s.n. (Syntype: B, destroyed; Lectotype: SP [photo seen], designated by Barros in Orchid Memories: 18. 2004. Minas Gerais: Poços de Caldas, 24 March 1920, F.C. Hoehne s.n. (Syntype: B, destroyed; Isosyntype: S, photo seen).

Acianthera velteniana Chiron \& Xim.Bols., Richardiana 13: 278. 2013. TYPE: Brazil. Espírito Santo, Domingos Martins, 780 m., L. Velten s.n. ex Chiron 13321 (Holotype: MBML, not located), syn. nov.

Barbosa Rodrigues first described Acianthera bidentula in the genus Pleurothallis R.Br. based on a specimen from Palmeiras, in Rio de Janeiro. A description first appeared in Revista de Engenharia in 1881 and was later reproduced in Genera et Species Orchidearum Novarum in 1882. Pridgeon and Chase (2001) proposed the new combination A. bidentula with a full and direct reference to "Pleurothallis bidentula Barb.Rodr., Gen. Spec. Orch. 2: 20. 1882.” This, however, is not the place of valid publication of $P$. bidentula. According to article 41.6 of the ICN, Pridgeon's and Chase's error does not affect the valid publication of their new combination.

According to Barbosa Rodrigues (1881, 1882), Pleurothallis bidentula was apparently a common species in the type locality for it was found covering tree trunks in the virgin forests of Palmeiras. As far as we could ascertain, Palmeiras is a locality in the municipality of Paulo de Frontin, formerly Rodeio, in the State of Rio de Janeiro. Barbosa Rodrigues collected extensively in Rodeio and described several new species from this area (see Duveen \& Toscano de Brito, 1991).

The type specimen of $P$. bidentula is lost and the only extant original material is the illustration that appeared in Barbosa Rodrigues's Iconographie des orchidées $d u$ Brésil, which is now deposited in the library of Rio de Janeiro Botanical Garden. This illustration, of which a copy is reproduced here (Fig. 7), was selected as lectotype by Chiron \& Bolsanello (2010). It was copied and reproduced in black and white in Cogniaux (1896) and reproduced in color in Sprunger et al. (1996). Despite the fact that Barbosa Rodrigues neither included measurements in his original description nor in his original illustration, plant and floral sizes of this species can be traced back through consultation of Barbosa Rodrigues's original illustration and Cogniaux's orchid illustration in Martius's Flora Brasiliensis (1896). Barbosa Rodrigues's original drawings show a small, repent plant whose ramicauls are c. $1 \mathrm{~cm}$ apart, the ramicauls are only c. $1 \mathrm{~cm}$ long, leaves are 2.0-2.5 $\mathrm{cm}$ long, $1.3-1.5 \mathrm{~cm}$ wide, the inflorescence is singleflowered, the dorsal sepal $8.5-9.0 \mathrm{~mm}$ long, $2.5 \mathrm{~mm}$ wide, and c. $1 \mathrm{~mm}$ fused with the synsepal at base, synsepal is c. $8 \mathrm{~mm}$ long, $6.5 \mathrm{~mm}$ wide, petals c. 3 $\mathrm{mm}$ long, $1.25 \mathrm{~mm}$ wide, and the lip c. $3.25 \mathrm{~mm}$ long, $2.25 \mathrm{~mm}$ wide across the lateral lobules. The column is enlarged and is shown in side view, but no enlargement ratio is provided. Based on other collections we studied, we believe the column was about $2.5 \mathrm{~mm}$ long. As far as flower color is concerned, the sepals are described as white, the dorsal sepal as having 3 lines, the synsepal suffused with purple, the lip and columnfoot purple. Cogniaux (1896) expanded significantly Barbosa Rodrigues's original description of Acianthera bidentula (as Pleurothallis bidentula) by adding measurements and information on the morphology of this species. Although his description mostly agrees with Barbosa Rodrigues's illustration, it was based not only on Rodrigues's illustration and description but also on examination of an additional Brazilian collection by L. Riedel, a specimen without precise provenance. We have been unable to locate Riedel's collection and confirm Cogniaux's determination. 

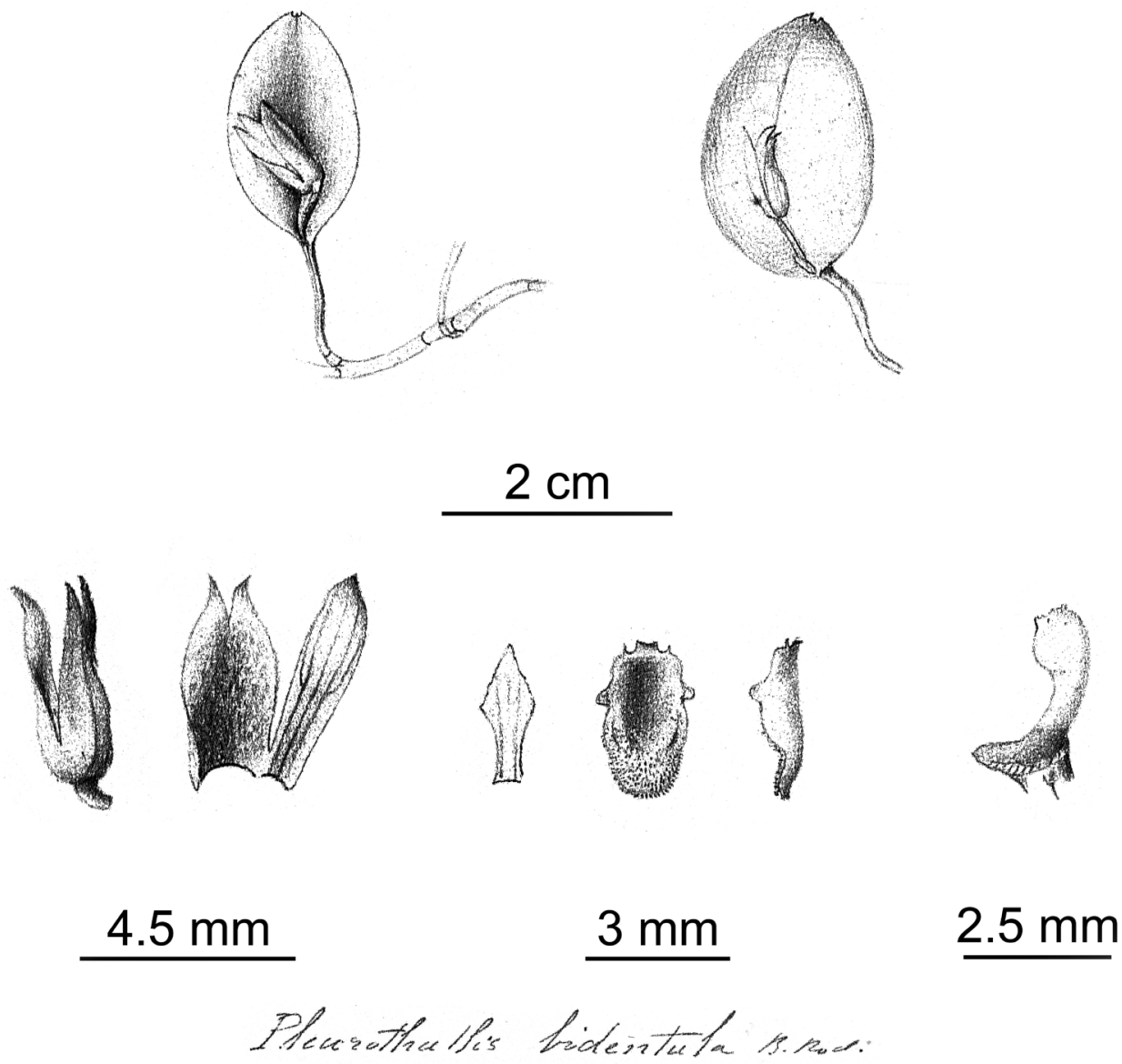

Figure 7. Acianthera bidentula (Barb.Rodr.) Pridgeon \& M.W.Chase. Barbosa Rodrigues's original illustration reproduced in Sprunger et al. (1996: vol. 1: 216, fig. B, as Pleurothallis bidentula Barb.Rodr.) and here modified to show this species with estimated scales. Reproduced with permission of the Reinhardt Verlag, Basel.

In the absence of an actual specimen, it is impossible to be sure of the true identity of Pleurothallis bidentula and any conclusion relies on interpretation of the only extant materials, namely, Barbosa Rodrigues's original illustration and description. Nevertheless, as illustrated in Barbosa Rodrigues's Iconographie, this species is shown to be distinct from all other species in the Acianthera saundersiana complex. The closest taxon, and certainly only a variant with slightly larger leaves, is $P$. vinosa Hoehne \& Schltr., which Pabst \& Dungs already reduced to synonymy in 1975 . The collections we have so far examined agree well with Barbosa Rodrigues's original illustration. With the exception of the dorsal sepal, which is narrower in Barbosa Rodrigues's drawings, overall floral size and morphology fit: dorsal sepal 10-12 mm long, 4-5 mm wide; synsepal $8-12 \mathrm{~mm}$ long, 6-8 $\mathrm{mm}$ wide; petals $2.5 \mathrm{~mm}$ long, 1-2 mm wide; lip 3.3-4.0 mm long, 2 $\mathrm{mm}$ wide, column c. $2.5 \mathrm{~mm}$ long. The dorsal sepal of $P$. bidentula is illustrated and described as fused to the synsepal at base. In the specimens examined, dorsal sepal is obscurely fused to the synsepal. One would feel tempted to use this feature to separate this species from others in this complex. However, fusion of dorsal sepal and synsepal can be observed in a certain degree in other species of this complex (e.g. A. glanduligera (Lindl.) Luer, A. rostellata (Barb. Rodr.) Luer, and A. serpentula) and cannot be used to distinguish this species.

Acianthera bidentula is apparently a common species in southeast Brazil. It has been found in Rio de Janeiro, São Paulo and Minas Gerais, and has been recently redescribed as $A$. velteniana Chiron \& Xms. 

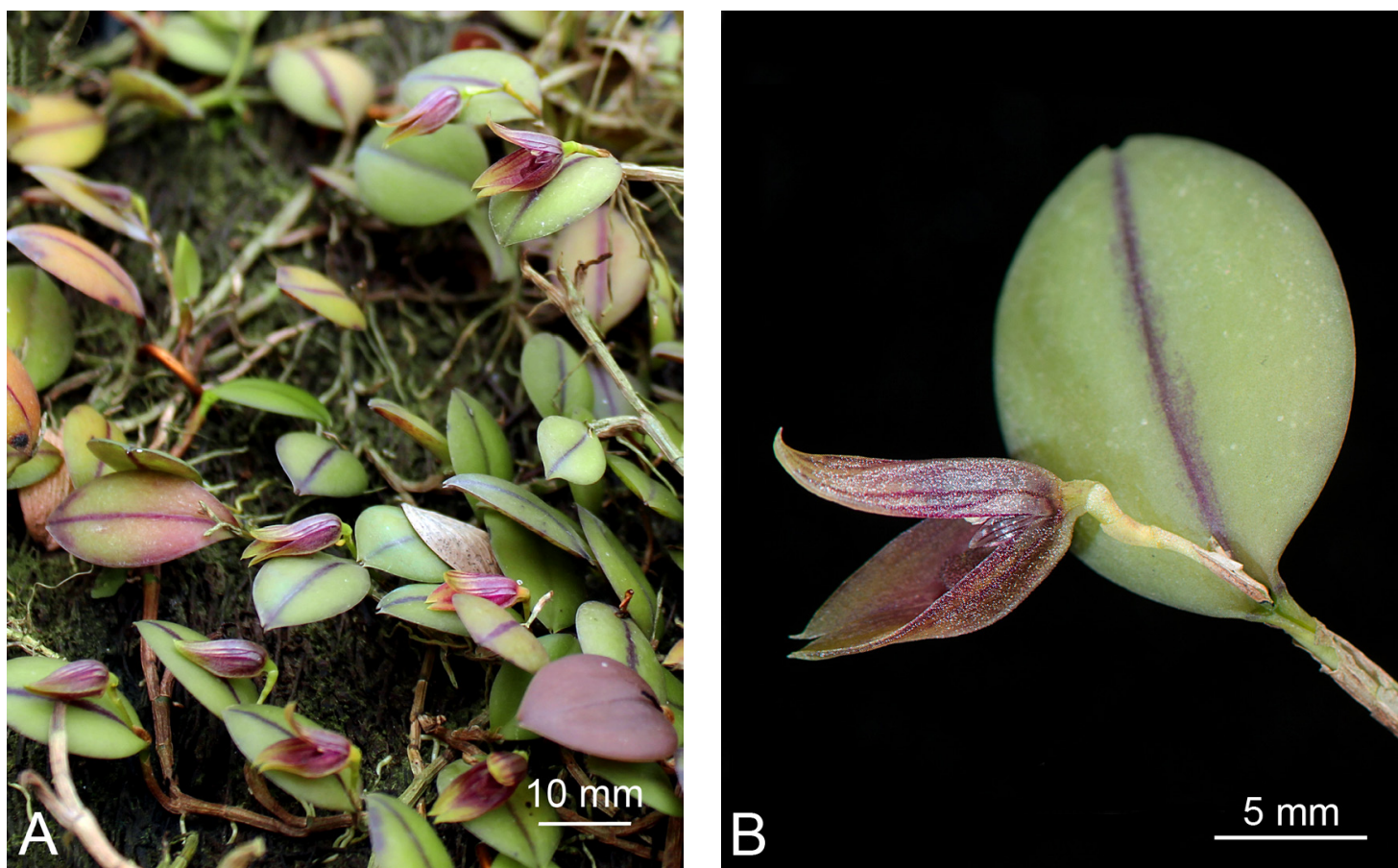

Figure 8. Acianthera bidentula (Barb.Rodr.) Pridgeon \& M.W.Chase. A - Habit. B - Flower in side view. A: Photographed by A. Toscano de Brito based on A. Toscano de Brito 2890 (UPCB); B: Photographed by Wade Collier based on $A$. Toscano de Brito 3289 (UPCB).

Bols. based on a collection from Domingos Martins, in Espírito Santo. A. velteniana is only distinguished from the lectotype of Pleurothallis bidentula by the slightly shorter, more elliptical, subdeltoid petals. However, petals of $A$. bidentula seems to vary even in the same individual and cannot be used to distinguish these two species. Figures $8 \mathrm{~A}-8 \mathrm{~B}$ are based on cultivated specimens from Rio de Janeiro. Figure 9 illustrates a collection from Domingos Martins, Espírito Santo, Brazil, the type locality of $A$. velteniana. We have been unable to locate the holotype of $A$. velteniana at MBML and apparently it has never been deposited there (L. Kolmman 2014, pers. com.). Barros et al. (2014) recorded A. bidentula for Rio Grande Sul, Santa Catarina, and Paraná. We have been unable to study any collection of $A$. bidentula from these Brazilian states. We believe that these records are based on misidentifications.

Additional Material Examined: BRAZIL: without collection data, purchased from Seidel in 2004, 15 March 2007, D.H. Baptista 071 (SEL), C.A. Luer illustr. 21115; without collection data, flowered in cultivation in Piracicaba, São Paulo, 15 March 2007, D.H. Baptista 058 (SEL), C.A. Luer illustr. 21128. Espírito Santo: Domingos Martins, flowered in cultivation by R.A. Kautsky 807, 3 Feb. 1991, $A$. Toscano de Brito 912 (SEL), C.A. Luer illustr. 20558. Rio de Janeiro: without precise locality, obtained from Orquidário Exdra in Rio de Janeiro, flowered in cultivation by M. Klingelfus s.n., 31 July 2014, A. Toscano de Brito 3289 (UPCB); without precise locality, flowered in cultivation by M. Klingelfus s.n., 24 July 2011, A. Toscano de Brito 2890 (UPCB).

\section{Nomenclatural Note on Acianthera serpentula}

Acianthera serpentula (Barb.Rodr.) F. Barros, Hoehnea 30: 187. 2003.

Basionym: Pleurothallis serpentula Barb.Rodr., Gen. Sp. Orchid. 2: 20.1882, replacement name for Pleurothallis punctata Barb.Rodr. 1877, non Ker Gawl. 1823, nec Lindl. 1835, nec Schltr. 1919. TYPE: BRAZIL. Minas Gerais, Caldas, J. Barbosa Rodrigues s.n. (Holotype: Lost; 

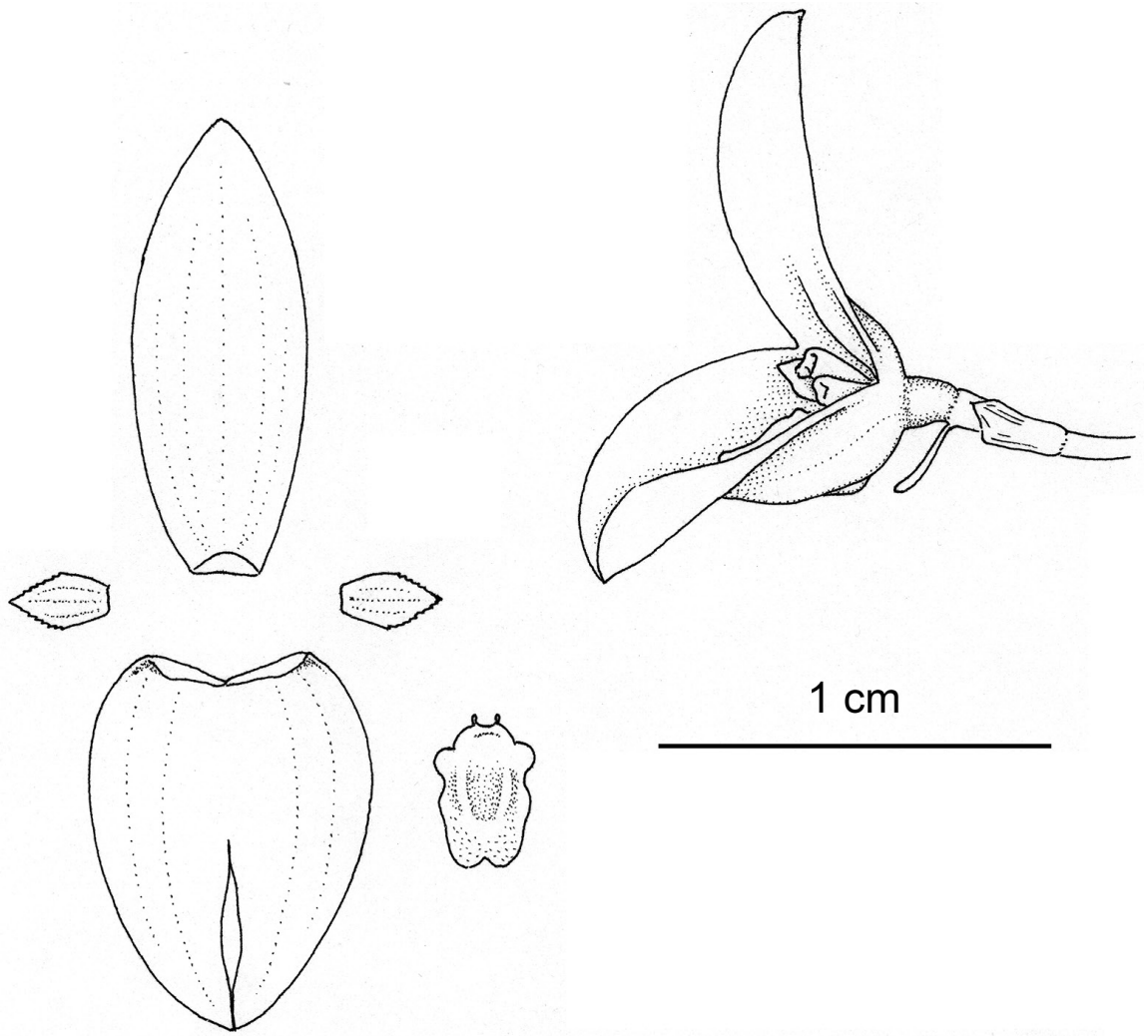

$1 \mathrm{~cm}$
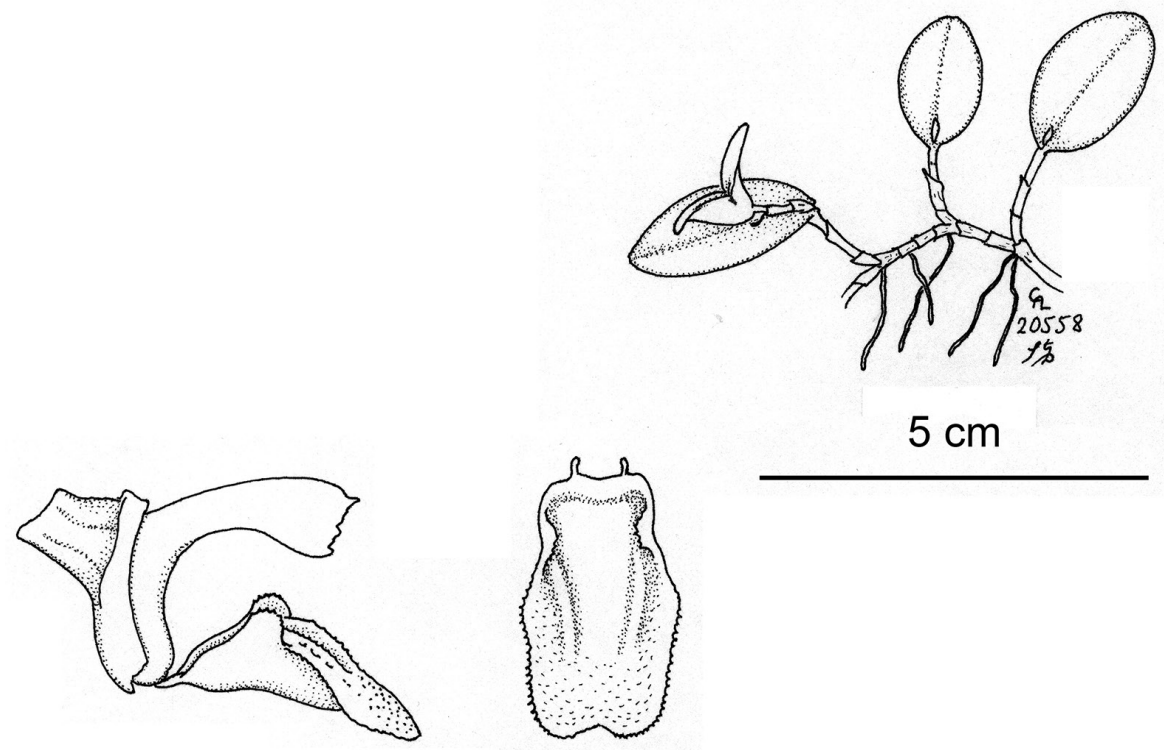

$5 \mathrm{~cm}$

\section{$3 \mathrm{~cm}$}

Figure 9. Acianthera bidentula (Barb.Rodr.) Pridgeon \& M.W.Chase. Drawn by C.A. Luer based on A. Toscano de Brito 912 (SEL). 
Lectotype designated by Barros in Hoehnea 30(3): 187. 2003: A. Regnell III-1649 (SP), here rejected. New lectotype designated here: tab. 167, fig. A, vol. 3 in Iconogr. Orchid. Brésil at the Library of Rio de Janeiro Botanical Garden, cited as tab. 407 A (then unpublished) in Barbosa Rodrigues (1877, as Pleurothallis punctata); copied and reproduced in black and white in Cogn., Fl. Bras. (Martius) 3(4), tab. 97, fig. 5.1896; reproduced in color in Sprunger et al. (1996, vol. 1: 225, fig. A).

Barbosa Rodrigues proposed the name Pleurothallis serpentula in 1882 to replace the illegitimate name P. punctata Barb.Rodr., which he published in 1877. As already stated elsewhere (e.g. Cribb \& Toscano de Brito 1966; Buzatto et al. 2013, Toscano de Brito 2013), Barbosa Rodrigues did not explicitly cite type specimens in his publications. Following standard rules of his time, he only cited provenance and flowering time of his collections. Most of Barbosa Rodrigues's illustrations were based on living material and are usually dated. The original plate of $P$. serpentula, which is reproduced in Sprunger et al. (1996, vol. 1: 225, fig. A), shows the following information: "Caldas 19 December 1876." When Barros (2003) transferred this species to the genus Acianthera, he claimed to have seen an isotype at SP, a collection made by A. Regnell, nr. III-1649, dated 26 December 1876. We have seen a photograph of this collection at SP and images of duplicates at $\mathrm{P}$ and $\mathrm{BR}$. There seems to exist a confusion with the collection dates of these specimens. Differently from the collection at SP, the specimen deposited at $\mathrm{P}$ is dated 28 June 1878, while a duplicate at BR is dated January (“Janv.") 1877. Even though it is difficult at present to ascertain a correct collection date for Regnell's materials, this is actually not relevant for the purpose of typification of this species. Regardless the collection date, Regnell's collection nr. III-1649 is not the type of P. serpentula.

When Barbosa Rodrigues (1882) proposed the new name Pleurothallis serpentula, he made a direct reference to the protologue of his P. punctata, the replaced synonym. He also cited Regnell's collection nr. III-1849 (most probably an error for "III-1649”). In Barbosa Rodrigues's Iconographie, Regnell's collection number III-1649 is found next to the floral analysis of $P$. serpentula and was later annotated there by his son, João Barbosa Rodrigues Jr. Regnell's collection is not cited anywhere in the original description of $P$. punctata and, therefore, it is not part of the protologue of this species. Barbosa Rodrigues based his illustration of $P$. punctata on a specimen he collected in Caldas, most certainly around the same date he made his illustration, i.e., on 19 December 1876. This collection should be considered the type of the name $P$. punctata and therefore the type of $P$. serpentula, the replacement name. Unfortunately, Barbosa Rodrigues's actual specimen has been lost. For this reason, we have selected as lectotype the original illustration in Barbosa Rodrigues's unpublished Iconographie, the only extant original material.

Acianthera serpentula is apparently related to A. saundersiana and to several other similar taxa in this complex. The floral color in Barbosa Rodrigues's original illustration, mainly the dorsal sepal, resembles that of A. calopedilon. However, A. serpentula is readily distinguished not only from these two species, but also from all others in this complex, by the shape of its oblong, slightly pandurate lip. It is apparently a rare species, whose actual specimens, living or preserved, we have so far not been able to study.

ACKNOWLEDGMENTS. The present paper is part of the project "The Pleurothallid Orchids of Brazil: Contributions to an inventory and an understanding of evolution, ecology and conservation," currently sponsored by the Marie Selby Botanical Gardens. We thank Wade Collier for providing photographs used in this article; the curator of SP, Maria Candida Mamede, for making available several images of types deposited at SP; Luiz Fillipe Varella, Jacques Klein, and Bryon Rinke, for providing specimens and additional information on Acianthera calopedilon; Maria Rita Cabral for providing useful information on A. velteniana; Kanchi Gandhi of AMES for his assistance in resolving some nomenclatural issues; Rudolf Jenny for help in obtaining literature; Nancy Karam and Wade Collier for help in assembling the illustrations; Stig Dasltröm for inking the illustrations, and the Pleurothallidinae Alliance for making it possible.

\section{Literature Cited}

Barros, F. de, Vinhos, F., Rodrigues, V.T., Barberena, F.F.V.A., Fraga, C.N., Pessoa, E.M., Forster, W. \& Menini Neto, L. (2014). Orchidaceae in Lista de espécies da flora do Brasil. Jardim Botânico do Rio de Janeiro. Published on the Internet: http://reflora.jbrj.gov.br/jabot/floradobrasil/ 
FB11051Accessed on: 17 Sept. 2014.

Barbosa Rodrigues, J. (1881). Orchideae rodeienses et alterae ineditae. Revista Engen., 3(7), 109-110.

Barbosa Rodrigues, J. (1882). Genera et species orchidearum novarum. Vol. 2. Typographia Nacional, Rio de Janeiro.

Chiron, G.R. \& Bolsanello, R.X. (2010). Quatre taxons nouveaus pour l'Éspírito Santo (Brésil) dans le morphogroupe Acianthera saundersiana (Orchidaceae). Richardiana, 10(4), 198-220.

Chiron, G.R. \& van den Berg, C. (2012). Révision taxinomique du genre Acianthera (Orchidaceae, Pleurothallidinae). Richardiana, 12(2), 59-77.

Cogniaux, A. 1896. Orchidaceae, Fl. Bras. (Mart.) 3(4): $317-672$.

Duveen, D. \& Toscano de Brito, A.L.V. (1991). Barbosa Rodrigues (1842--1909) and his round-up of orchids at Rodeio. Orchid Digest, 55(4), 149-154.

Luer, C.A. (1977). Icones Pleurothallidinarum (Orchida- ceae). Miscellaneous Species in the Pleurothallidinae. Selbyana, 3(3-4), 382.

Luer, C.A. (2004). Icones Pleurothallidinarum XXVI. Systematics of Pleurothallis subgenus Acianthera (Orchidaceae). Monogr. Syst. Bot. Missouri Bot. Gard., 95, 64--65

Pabst, G.F.J. \& Dungs, F. (1975). Orchidaceae Brasilienses, Vol. 1. Brücke-Verlag Kurt Schmersow, Hildesheim.

Pridgeon, A.M. \& Chase, M.W. (2001). A phylogentic reclassification of the Pleurothallidinae (Orchidaceae). Lindleyana, 16(4), 235-271.

Saunders, W.W. (ed.) (1872). Refugium Botanicum or figures and descriptions from living specimens of little known or new plants of botanical interest, Vol. 2. John van Voorst, London.

Sprunger, S., Cribb, P. J. \& Toscano de Brito, A. L. V. (eds.). (1996). João Barbosa Rodrigues - Iconographie des orchidées du Brésil, Vol. 1: The illustrations. Friedrich Reinhardt Verlag, Basel. 